\title{
URINARY EXCRETION OF ANDROGENIC SUBSTANCES AFTER INTRAMUSCULAR AND ORAL ADMINISTRATION OF TESTOSTERONE PROPIONATE TO HUMANS ${ }^{1}$
}

\author{
By RALPH I. DORFMAN AND JAMES B. HAMILTON \\ (From the Adolescence Study Unit, the Laboratory of Physiological Chemistry, and the \\ Department of Anatomy, Yale University School of Medicine, New Haven)
}

(Received for publication September 12, 1938)

The urinary excretion of estrogens following administration of female sex hormones has been compared with the relief obtained from hot flushes and other phenomena accompanying the menopause (1) and has been studied with regard to the percentage of the administered material which appears in the urine (3 to 12 per cent) (2). Studies of the excretion of urinary androgens following the treatment of patients with testosterone propionate are reported below with regard to $(a)$ the rapidity of the appearance and comparative levels of excretion in oral and intramuscular treatment, $(b)$ the percentage of recovery in the urine of administered material, and (c) the evaluation of urinary levels of androgens as criteria of effective levels of male hormone in the body.

\section{METHODS, MATERIALS, AND SUBJECTS}

All urine samples were collected on a 24-hour basis and extracted with benzene in a continuous extractor according to the method previously described (3). The assays for androgenic activity contained in the urine extracts were performed on the day-old chick's comb (4). A minimum of 15 and usually 20 chicks were used for each assay. The accuracy of the determinations is considered to be \pm 25 per cent and probably greater as can be calculated from previous data (4). All values are expressed as international units (I.U.) per 24 hours. The international unit of androgenic activity is that evoked by $0.1 \mathrm{mgm}$. of androsterone.

The androgen used was testosterone propionate. ${ }^{2}$ Intramuscular administration employed a standard dose of $20 \mathrm{mgm}$. dissolved in $1 \mathrm{cc}$. of peanut oil, since the amount and the type of oil influences the absorption (5). Injections were made intramuscularly into the buttocks or upper arms.

1 This investigation was aided in part by grants from the Fluid Research Fund of Yale University School of Medicine, the General Education Board of the Rockefeller Foundation, and The International Cancer Research Foundation.

2 Furnished through the courtesy of the Ciba Company, under the trade name Perandren.
Crystalline testosterone propionate was given per os in disc-shaped tablets $0.5 \mathrm{~cm}$. in width, $0.3 \mathrm{~cm}$. in diameter. Tablets were taken on an empty stomach at spaced intervals during waking hours: 16 hour before breakfast, 1 hour before lunch, 1 hour before dinner, and in the evening before retiring.

The subjects are 2 men with organic and functional evidence of deficient testicular secretion. Case 1 is a 35-year-old man who had lived until the age of 35 with a single descended testis. He has a wife and 2 children. Following surgical removal of the testis at the age of 35 , castration phenomena (6), including the following, appeared: atrophy of the genitalia, muscular weakness and fatigue (7), absence of penile erection $(8,9)$, presence of vasomotor phenomena such as may be found in women at the menopause, skin pallor, and inability to $\tan (10)$. Before androgenic administration, the level of output of male hormone in 4 urine assays covering 7 days, taken from a period of weeks, showed a daily average of $13.5 \mathrm{I}$.U. This is far below the levels of androgen excretion of normal adult men $(11,12,3)$. Still further evidence that if any abdominal testis were present it did not secrete large amounts of androgens was the negative clinical response obtained with 16 injections of large amounts of anterior pituitary-like substance, 100 rat units (R.U.) given three times weekly.

Case 2 is a 27-year-old sexually underdeveloped man, described in detail elsewhere (8), who exhibited a like condition save that the genitalia instead of undergoing atrophy had never developed. The testes did not respond to injections of 100 R.U. of anterior pituitarylike material given 3 times weekly for 9 weeks.

\section{RESULTS}

A. Intramuscular administration. Intramuscular injections of $20 \mathrm{mgm}$. of testosterone propionate were given daily to Case 1 for 30 successive days. The resultant increased excretion of urinary androgens is shown in Table I. The average daily output prior to injections was 13.5 I.U. By the 3d day of injection, the output was 50 I.U. at which time some of the clinical symptoms of androgen deficiency remained, particularly the vasomotor phenomena. This is perhaps correlated with the fact that the longer the period 
TABLE I

Urinary androgenic activity before, during, and after intramuscular injections of testosterone propionate *

\begin{tabular}{lcc}
\hline \hline Day of treatment & $\begin{array}{c}\text { Day after } \\
\text { cessation of } \\
\text { treatment }\end{array}$ & $\begin{array}{c}\text { Urinary } \\
\text { androgenic } \\
\text { activity }\end{array}$ \\
\hline 0 & & $\begin{array}{r}\text { I.U. per day } \\
7\end{array}$ \\
0 & & 21 \\
\hline 3 & & 50 \\
4 & 93 \\
9,6 & 47 \\
$12,13,25,26,27$ & & 78 \\
30 & & 68 \\
\hline & & 94 \\
\hline & 8,9 & 38 \\
& 30 & 13 \\
& 37 & 13 \\
\hline
\end{tabular}

* Intramuscular injections of $20 \mathrm{mgm}$. of testosterone propionate (equivalent to $1110 \mathrm{I}$.U.) in $1 \mathrm{cc}$. of peanut oil were given Case 1 daily for 30 successive days. The urinary output of comb growth-stimulating materials reached the levels of normal men the 3d day of injection and remained so during the $\mathbf{3 0}$ days of treatment. Thirty days after the end of injections, the amount in the urine was again down to a pre-injection level. Castration signs disappeared during this treatment.

of androgen injection the greater the suppression of pituitary hyperactivity (13).

This high level of androgen excretion was maintained throughout the period of treatment, as shown by assays of 11 out of the 16 remaining days of injection. The average daily output of 12 days, ranging from the $3 \mathrm{~d}$ to the 30 th day was 68.9 I.U., an increase of 510 per cent. In all determinations this level remained within the range of 40 to $100 \mathrm{I}$.U. which is the range for normal men as determined by several groups of workers $(11,12,3)$. After the first few days castration symptoms remained absent throughout the course of treatment. Thus, with the intramuscular injections which maintained normal ranges of urinary androgens, the patient remained symptom-free.

Eight to 9 days after the cessation of injections, the daily output was still 38 I.U. Although this was an increase of 281 per cent over the castrate level and can hardly be considered lower than normal levels, castration signs were again of considerable severity.

Determinations done 30 and 37 days respectively after the end of treatment showed 13 I.U., a return to low pre-injection levels.
$B$. Oral administration. Daily oral administration of $60 \mathrm{mgm}$. of testosterone propionate was given to Case 1. An immediate high level of urinary androgen was obtained. A 24-hour specimen between the 36th and 60th hour after ingestion of the first tablet contained 137 I.U., an increase of 124.5 I.U. over the pre-treatment level of daily excretion (Table II). This increase of

TABLE II

Urinary androgenic activity before and during oral administration *

\begin{tabular}{ccc}
\hline Case & Day of treatment & $\begin{array}{c}\text { Urinary } \\
\text { androgenic } \\
\text { activity }\end{array}$ \\
\hline & & I.U. per day \\
1 & 0 & 7 \\
& 0 & 21 \\
& 0 & 13 \\
& 0 & 137 \\
\hline 2 & 22 & 500 \\
\hline & 0 & 14 \\
& 0 & 18 \\
& 2 & 38 \\
& $7,9,11,12$ & 94 \\
& 14 & 264 \\
\hline
\end{tabular}

* Oral administration of $60 \mathrm{mgm}$. of testosterone propionate (equivalent to 3330 I.U.) in tablet form was given Case 1 daily for 15 days followed by $120 \mathrm{mgm}$. (equivalent to 6660 I.U.) daily for the next 7 days. Case 2 received 60 $\mathrm{mgm}$. of testosterone propionate daily for 14 days. The urinary androgenic activity far exceeded the levels for normal men, but the patients were only slightly relieved of castration phenomena.

922 per cent in urinary androgen activity was accompanied by slight, if any, clinical improvement. The amount ingested was then raised to $120 \mathrm{mgm}$. of testosterone propionate daily and after 3 days the daily androgen excretion was 500 I.U., an increase of 3703 per cent over the pre-treatment level. Castration symptoms still continued.

Case 2 had an average urinary output of 16 I.U. before oral administration was begun. By the $2 \mathrm{~d}$ day of daily oral administration of 60 $\mathrm{mgm}$. of testosterone propionate, 38 I.U. were excreted in a 24-hour specimen of urine (Table II). Pooled samples for the 7th, 9th, 11th and 12th days of treatment gave an average of 94 I.U. By the 14th day 264 I.U. were excreted, an increase of 1560 per cent over the level before treatment. A moderate amount of clinical relief occurred but it was not equal to that obtained 
with $1 / 6$ of this dose given subcutaneously in injections of $20 \mathrm{mgm}$. 3 times weekly.

If the samples assayed could be considered representative, a very rough estimate in Case 1 of the percentage of recovery in the urine of comb growth-stimulating material with daily subcutaneous injections might be made as in Table III.

TABLE III

Percentage of administered androgenic material recovered in the urine

\begin{tabular}{|c|c|c|}
\hline & $\begin{array}{c}\text { Average } \\
\text { urinary } \\
\text { androgen } \\
\text { in } 24 \text { hours }\end{array}$ & Total \\
\hline $\begin{array}{l}\text { Days } 1 \text { to } 10 \text { of treatment. } \\
\text { Days } 11 \text { to } 30 \text { of treatment. } \\
\text { Days } 1 \text { to } 15 \text { after treatment }\end{array}$ & $\begin{array}{r}1 . U . \\
\ldots .67 .00 \\
\ldots .72 .33 \\
\cdots .38 .00\end{array}$ & $\begin{array}{r}I . U . \\
670 \\
1446 \\
570\end{array}$ \\
\hline
\end{tabular}

Total excretion expected over these $\mathbf{4 5}$ days without treatment (at 13.5 I.U. daily) . . . . . . . . . 607

Net excretion . . . . . . . . . . . . . . . 2079

The $600 \mathrm{mgm}$. of administered testosterone propionate is equivalent to $502 \mathrm{mgm}$. of testosterone.

If urinary androgen is testosterone:

Since 1 I.U. of testosterone $=0.015 \mathrm{mgm}$. (cf. Koch (17)) then 2079 I.U. (net excretion) $=31.190 \mathrm{mgm}$.

Percentage recovery $=\frac{31.19 \mathrm{mgm}}{509 \mathrm{mgm} .} \times 100=6.2$ per cent

If urinary androgen is androsterone:

Since 1 I.U. of androsterone $=0.100 \mathrm{mgm}$.

then 2079 I.U. (net excretion) $=207.900 \mathrm{mgm}$.

Percentage recovery $=\frac{207.9 \mathrm{mgm}}{502 \mathrm{mgm} .} \times 100=41.4$ per cent

If urinary androgen is dehydroisoandrosterone:

Since 1 I.U. of dehydroisoandrosterone $=0.300 \mathrm{mgm}$. then 2079 I.U. (net excretion) $=623.700 \mathrm{mgm}$.

Percentage recovery $=\frac{623.7 \mathrm{mgm}}{502 \mathrm{mgm} .} \times 100=124.2$ percent

If urinary androgens are an equal mixture of dehydroisoandrosterone and androsterone:

Percentage recovery $=\frac{313.5 \mathrm{mgm} .}{502 \mathrm{mgm} .} \times 100=62.4$ per cent

If the androgenically-active material is excreted in the form of testosterone, the percentage of recovery is 6.2. If it is excreted as androsterone, the recovery is 41.4 per cent, as dehydroisoandrosterone 124.0 per cent, and as equal mixtures of androsterone and dehydroisoandrosterone 62.4 per cent.

The possibility that all of the testosterone propionate is converted into dehydroisoandrosterone is unlikely since, as shown in Table III, this would mean an excretion of more material than was administered.

There is no proof that the pre-treatment level of male hormone secretion by the body was maintained during the injection of the testosterone propionate, especially since this intramuscular administration of androgen greatly decreased the urinary level of gonadotropic (follicle-stimulating) substance in this patient (14). If none of the excreted androgen were of endogenous 'origin, more of the amount excreted would be considered as recovered from the administered hormone. This would make estimates of the amount recovered as much as $1 / 3$ higher.

\section{DISCUSSION}

Even if the figures for recovered hormone are no higher than listed, there remain the obvious facts that (1) daily intramuscular injections of $20 \mathrm{mgm}$. of testosterone propionate maintained excretion levels at approximately those determined for normal men and that castration symptoms disappeared during this treatment, and (2) orallyadministered crystalline testosterone propionate was readily absorbed from the gastro-intestinal tract and eliminated in large amounts through the kidneys; since, however, no satisfactory clinical relief was afforded even when absorption was continued during 16 hours of the day, it seems likely that the material was eliminated with great rapidity. The figures indicate that increasing the oral dose of crystalline testosterone propionate can be expected to result in only exceedingly brief levels of hormone in the fluids and tissues of the body. In the maintenance of effective levels in the body by oral means there must be a balance between slow absorption to avoid prompt elimination by the kidneys and ready absorption to prevent waste in the feces. Furthermore, damage $(15,16)$ from large doses of male hormone may be incurred, especially in the kidney and the vascular system.

The transient presence of orally-administered testosterone propionate within the body and the rapid appearance of large quantities of androgenic material in the urine raise the question of threshold levels. It may be that when a certain threshold is reached, the hormone above this level is 
excreted in the urine. In this connection it is interesting to note that in adrenal virilism in women, enormous titers of androgen activity in the urine may be observed, but the masculinization does not proceed beyond that of the normal male.

The urinary level of androgen is an accurate reflection of the level in the tissues and fluids of the body only when the supply in circulation is at a maintained rate. Temporary presence of a large amount in the body would produce a large urinary excretion. In other words, evaluation of levels of androgens in the body by comparison of one urine titer with another would be misleading if the androgen precursors were not present over the same general length of time. Further, measurements of urinary androgenic activity should be expected to account only with inaccuracy if there were great variations in the amount present in the body during this time.

If the androgens secreted by the body were from the testes and in the form of testosterone and had a percentage of recovery in the urine like that from intramuscular injections in Case 1, there would be secreted in $\mathbf{2 5}$ gram testes of a man, 22 I.U. per gram every 24 hours.

\section{SUM MARY}

1. In the patient with low levels of testicular secretion both intramuscular and oral administration of testosterone propionate produce an increase in the androgenic activity of the urine.

2. With intramuscular injections of $20 \mathrm{mgm}$. daily, Case 1 showed an increase in output to normal levels and clinically a disappearance of castration phenomena. A 24-hour titer of 50 I.U. was obtained on the $3 \mathrm{~d}$ day of administration. The average of 6 assays covering 12 of the 30 days of injection was 68.9 I.U., with a range from 47 to 94 I.U.

3. Tablets per os of 60 to $120 \mathrm{mgm}$. daily gave 24-hour urine readings as high as 500 I.U. in Case 1, and 264 I.U. in Case 2. These large excretions were not accompanied by as good clinical relief as obtained with $1 / 6$ to $1 / 7$ the amount taken intramuscularly and with lesser androgenic activity of the urine.

4. Absorption of the large amounts of androgen can take place through the gastro-intestinal tract with what appears to be rapid elimination through the kidneys. It is suggested that there may be a threshold for the substance in the body and that rapid disposition is made of an excess. Oral means of administration should be considered from the standpoint of material lost not only through the feces but also excreted in the urine.

5. Urine assays as an indication of the presence of hormone in the body may be misleading if the hormone in the body is present only irregularly. For example, enormous quantities of urinary androgen were found with an oral method that appeared to give only transient levels in the body.

6. A rough estimation of the percentage of the androgenic material recovered in the urine is 6.2 per cent, if it be in the form of testosterone, 41.4 per cent if androsterone, 62.4 per cent if an equal mixture of androsterone and dehydroisoandrosterone.

\section{BIBLIOGRAPHY}

1. Mazer, C. and Isreal, S. L., Studies on the optional dosage of estrogens; an experimental and clinical evalution. J. A. M. A., 1937, 108, 163.

2. Kemp, T. and Pedersen-Bjergaard, $\mathrm{K}$., Absorption and excretion of oestrone by the human organism. - Lancet, 1937, 2, 842.

3. Gallagher, T. F., Peterson, D. H., Dorfman, R. I., Kenyon, A. T. and Koch, F. C., The daily urinary excretion of estrogenic and androgenic substances by normal men and women. J. Clin. Invest., 1937, 16, 695.

4. Dorfman, R. I. and Greulich, W. W., The response of the chick's comb to naturally occurring androgens and estrogens. Yale J. Biol. and Med., 1937, $10,80$.

5. Parkes, A. S., Increasing the effectiveness of testosterone. Lancet, 1936, 2, 674.

6. Hamilton, J. B. and Hubert, G., Unpublished data.

7. Miller, N. E., Hubert, G. and Hamilton, J. B., Mental and behavioral changes following male hormone treatment of adult castration, hypogonadism and psychic impotence. Proc. Soc. Exper. Biol. and Med., 1938, 38, 538.

8. Hamilton, J. B., Treatment of sexual underdevelopment with synthetic male hormone substance. Endocrinology, 1937, 21, 649.

9. Hamilton, J. B., Induction of penile erection by male hormone substances. Endocrinology, 1937, 21, 744.

10. Hamilton, J. B. and Hubert, G., Photographic nature of tanning of the human skin as shown by studies of male hormone therapy. Science, 1938, 88, 481.

11. Dingemanse, E., Borchardt, $H$. and Laqueur, E., Capon comb growth-promoting substances ("male 
hormones") in human urine of males and females of varying age. Biochem. J., 1937, 36, 500.

12. Callow, R. K., Extraction of male hormone from urine for biological assay. Lancet, 1936, 2, 565.

13. Hamilton, J. B. and Wolfe, J. M., The effect of synthetic androgen upon the gonadotropic potency of the anterior pituitary. Endocrinology, 1938, 22, 360 .

14. Catchpole, H. and Hamilton, J. B., Unpublished data.
15. Hamilton, J. B., Precocious masculine behavior following administration of synthetic male hormone substance. Endocrinology, 1938, 23, 53.

16. Hamilton, J. B. and Dorfman, R. I., Influence of various solvents upon the length and strength of the action of synthetic male hormone, testosterone propionate. (To be published.)

17. Koch, F. C., The male sex hormones. Physiol. Rev., 1937, 17, 180. 